\title{
Azathioprine and Methotrexate impaired the morphology and functions of the testes in adult wistar rats
}

\author{
AKINLOLU, A. A. ${ }^{*}$, AKINOLA, O. B. ${ }^{2}, \mathrm{KHOBE}, \mathrm{P}^{3}, \mathrm{OBASI}, \mathrm{K}^{3}{ }^{3}$ and DADA, O. ${ }^{3}$ \\ ${ }^{1} \mathrm{PhD}$ Anatomy (in-view), Department of Anatomy, Faculty of Basic medical Sciences, \\ University of Ilorin, P.M.B. 1515, Ilorin, Kwara State, Nigeria \\ ${ }^{2} \mathrm{PhD}$ Anatomy, Department of Anatomy, University of Ilorin, P.M.B. 1515, Ilorin, Kwara State, Nigeria Khobe \\ 3B.Sc. Anatomy, Department of Anatomy, University of Ilorin, P.M.B. 1515, Ilorin, Kwara State, Nigeria \\ *E-mail: a3akin@gmail.com; akinlolu.aa@unilorin.edu.ng
}

\begin{abstract}
Introduction: Azathioprine and Methotrexate are both used in the treatment of cancer; and are classified as cytotoxic drugs with reported adverse effects such as oxidative damage to the DNA/RNA, the testes and sperm cells. This study, therefore, tested the hypothesis that Azathioprine and Methotrexate administrations impair the morphology and functions of the testes in adult male wistar rats. Methods: Azathioprine (50-150mg per day) and Methotrexate $(2.5 \mathrm{mg}$ per week) are used in the treatment of cancer in adult Man. We tested the hypothesis that Azathioprine and Methotrexate impair the morphology and functions of testes in rats. Forty adult male wistar rats (150-230g) were employed in the study: Control Group I received physiological saline while Experimental Groups II - V received oral administrations of $5 \mathrm{mg} / \mathrm{kg} /$ bodyweight of Azathioprine per day, $15 \mathrm{mg} / \mathrm{kg} /$ bodyweight of Azathioprine per day, $8 \mathrm{mg} / \mathrm{kg} /$ bodyweight of Methotrexate per week and $20 \mathrm{mg} / \mathrm{kg} /$ bodyweight of Methotrexate per week respectively for 35 days. Results: Histological examinations of the testes of rats of Groups II - V showed dose-dependent morphological anomalies such as fewer collagen fibers of connective tissues, disrupted seminiferous tubules and scanty spermatozoa when compared to rats of Group I. Statistical analyses showed dose-dependent elevated levels $(\mathrm{P} \leq 0.05)$ of superoxide dismutase and malondialdehyde in testes homogenates of rats of Groups II - V when compared to rats of Group I. This implied increased oxidative stress in rats of Groups II - V. Evaluations of Follicle Stimulating Hormone and Testosterone showed dose-dependent significantly elevated levels $(\mathrm{P} \leq 0.05)$ in rats of Groups II $-\mathrm{V}$ when compared to rats of Group I. Conclusions: Our findings are consistent with the stated hypothesis.
\end{abstract}

Keywords: Azathioprine, Methotrexate, testes, morphology, functions.

\section{Introduction}

The testis is the main organ of male fertility and produces hormones and spermatozoa. (JUNQUEIRA and CARNEIRO, 2007; GUYTON and HALL, 2011). Each testis is surrounded by a capsule of dense, irregular collagenous connective tissue, the tunica albuginea; and an inner layer of highly vascularized loose connective tissue, the tunica vasculosa. It is composed of approximately 250 testicular lobules, each containing about four seminiferous tubules. The seminiferous tubules are separated by interstitial connective tissues composed of interstitial cells (Leydig cells), blood, lymphatic vessels and nerves. The seminiferous epithelium consists of two types of cells: Sertoli or supporting cells and cells of the spermatogenic lineage. (JUNQUEIRA and CARNEIRO, 2007; GUYTON and HALL, 2011).

Leydig cells secrete the testosterone hormone while seminiferous tubules produce sperm cells. (JUNQUEIRA and CARNEIRO, 2007). Testosterone hormone controls male pubertal development, testicular growth and spermatogenesis. The synthesis and release of testosterone is, however, under the regulation of hypophyseal hormones: the Follicle Stimulating Hormone (FSH) and Luteinizing Hormone (LH). (JUNQUEIRA and CARNEIRO, 2007; GUYTON and HALL, 2011).

Azathioprine is an immunosuppressant drug which is used to inhibit the body's rejection of transplanted tissues. Azathioprine is cleaved chemically by gluthatione $-S$ - transferase to produce 6 - mercaptopurine in red blood cells. Azathioprine and 6 - mercaptopurine are purine analogues which interfere with adenine and guanine ribonucleosides required for the synthesis of deoxyribonucleic acid (DNA). Azathioprine, therefore, gives rise to non-functional DNA and ribonucleic acid (RNA); and DNA anomalies such as DNA strand breaks, DNA - protein cross links and chromatid damage. (TRIPATHI, 2003; BRITISH MEDICAL ASSOCIATION and ROYAL PHARMACEUTICAL SOCIETY, 2013; BLASIAK et al., 2002). It inhibits the proliferation of Tand B- lymphocytes and suppresses bone marrow activities. (TRIPATHI, 2003; BRITISH MEDICAL ASSOCIATION and ROYAL PHARMACEUTICAL SOCIETY, 2013; BLASIAK et al., 2002). Due to its antiproliferative activity, Azathioprine is used in the treatment of cancer. (TRIPATHI, 2003; BRITISH MEDICAL ASSOCIATION and ROYAL PHARMACEUTICAL SOCIETY, 2013; BLASIAK et al., 2002).

Methotrexate is a folic acid antagonist which inhibits dihydrofolate reductase and prevents the formation of tetrahydrofolic acid (THFA); thereby inhibiting DNA replication, cellular hyperplasia, lymphocytes and macrophage functions. (TRIPATHI, 2003). Folates are required for 
the transfer of one - carbon unit needed for the syntheses of purines, thymidines and amino acids. The inhibitory effects of Methotrexate on the activities of dihydrofolate reductase limit the release of one - carbon units required for the synthesis of purines and prevent the conversion of deoxyuridylate to thymidylate in DNA replication and cell reproduction. (TRIPATHI, 2003; BRITISH MEDICAL ASSOCIATION and ROYAL PHARMACEUTICAL SOCIETY, 2013; BLASIAK et al., 2012). It is used in the treatment of cancer, rheumatoid arthritis and autoimmune diseases. (TRIPATHI, 2003; BRITISH MEDICAL ASSOCIATION and ROYAL PHARMACEUTICAL SOCIETY, 2013).

Azathioprine and Methotrexate are both used in the treatment of cancer; and are classified as cytotoxic drugs with reported adverse effects such as oxidative damage to the DNA/RNA, the testes and sperm cells. $(3,5)$. The testis produces spermatozoa via spermatogenesis. (JUNQUEIRA and CARNEIRO, 2007; GUYTON and HALL, 2011). Spermatogenesis would clearly be affected by genotoxic and cytotoxic agents such as Azathioprine and Methotrexate. This study, therefore, tested the hypothesis that Azathioprine and Methotrexate administrations impair the morphology and functions of the testes in adult male wistar rats.

\section{Materials and Methods}

\subsection{Ethical approval}

Ethical approval was sought and received from the Department of Anatomy of the University of Ilorin, Ilorin, Kwara State, Nigeria. The protocols for the use of animals in scientific research were strictly adhered to in compliance with World Health Organization's provisions.

\subsection{Animal care and feeding}

Forty apparently healthy adult male wistar rats weighing 150-230g and aged 10-12 weeks obtained from the colony bred of the animal house of the Department of Anatomy, University of Ilorin, Kwara State, Nigeria were employed in the study. They were housed in individual cages in a well ventilated and fumigated room with ambient temperature and good lighting. All rats were fed with standard pellet diet (Kusa Ventures Nigeria Limited, Ilorin) and received water ad libitum. The rats were acclimatized for seven days before the start of experimental procedures. The weight of each rat was taken daily using the high precision electronic analytical weighing balance (Denver, USA). Furthermore, each rat was examined daily for possible behavioural and gross morphological or physical changes.

\subsection{Chemicals, reagents and laboratory equipments}

Azathioprine $50 \mathrm{mg}$ (Imuran) and Methotrexate $2.5 \mathrm{mg}$ (Neotrexate) tablets were products of GlaxoSmithKline, United Kingdom; Normal saline solution, Distilled water, Phosphate buffer, EDTA, Sulphuric (VI) acid $\left(\mathrm{H}_{2} \mathrm{SO}_{4}\right)$, and Hydrochloric acid (HCI) were products of $\mathrm{BDH}$ Chemical Limited, Poole, England; Tris buffers, 2-thiobarbituric acid (TBA), Phosphoric acid and Pyrogallol were products of Sigma Chemicals, St. Louis USA; and assay kits for Superoxide dismutase, Testosterone and Follicle Stimulating
Hormones were products of Randox Laboratories, United Kingdom. Spectrophotometer (Jenway Model 6405, UV/ visible), mortar and pestle, weighing balance, centrifuge, $\mathrm{pH}$ meter (Rex model pHs 25), Norm-jet needles and syringes (Norm-jet Inc. Tuttlinger, Germany) and anticoagulant tubes (Sterling products, England).

\subsection{Administrations of drugs}

Azathioprine $50 \mathrm{mg}$ (Imuran) and Methotrexate $2.5 \mathrm{mg}$ (Neotrexate) tablets were purchased from Momrota Pharmacy, opposite University of Ilorin Teaching Hospital, Ilorin, Kwara State, Nigeria. The treatment dosage of Azathioprine is $50-150 \mathrm{mg}$ daily and that of Methotrexate is $2.5 \mathrm{mg}$ per week in Man. The drug tablets were grinded into powdery forms using sizeable mortar and pestle in an environment free of wind and then dissolved in $10 \mathrm{mls}$ of distilled water.

The male wistar rats employed in the study $(\mathrm{n}=40)$ were divided into five groups; each comprising of eight rats. Rats of Control Group I received physiological saline daily. Rats of Experimental Groups II - V, however, received corresponding oral administrations of $5 \mathrm{mg} / \mathrm{kg} /$ body weight of Azathioprine per day, $15 \mathrm{mg} / \mathrm{kg} /$ body weight of Azathioprine per day, $8 \mathrm{mg} / \mathrm{kg} /$ body weight of Methotrexate per week and $20 \mathrm{mg} / \mathrm{kg} /$ body weight of Methotrexate per week respectively for 35 days. Doses of administered drugs were determined from previous studies which determined the toxicity profiles of Azathioprine or Methotrexate using same or similar doses in rat models. (PADMANABHAN, TRIPATHI, VIKRAM et al., 2009; ELELAIMY, ELFIKY, HASSAN et al., 2012). Oral administration of drugs was done with the use of a $5 \mathrm{ml}$ syringe and a flexible feeding tube long enough to reach the stomach through the oesophagus.

\subsection{Excision and fixation of the testes}

The rats of Groups I - V were sacrificed on Day 35 by humane method using chloroform inhalation. The animals were kept in a dessicator with cotton wool soaked in chloroform. The testes were harvested after an abdominal incision was extended to the perineal region from the abdomen. The scrotal sacs were opened and the whole testis was removed, taken out and fixed in $10 \%$ formal saline of at least five times its volume.

\subsection{Histological analyses of the testes}

Histological examinations of the fixed testes of rats of Groups I - V were carried out using Haematological and Eosin techniques as earlier described. (AKINLOLU, OTULANA, OWOEYE et al., 2007). After complete fixation of the testes, blocks were embedded in paraffin wax and sections cut at $5 \mu \mathrm{m}$ (micron). The tissue sections were stained with haematoxylin and eosin and mounted in Canada balsam. Microscopic examination of the sections was then carried out under the Olympus light microscope to determine possible cytoarchitectural changes of the testes following administrations of Azathioprine or Methotrexate. Masson's trichrome which is a special three-colour staining protocol well suited for distinguishing cells from surrounding connective tissues was used to examine the effects of Azathioprine or Methotrexate on collagen fibres of testicular connective tissues as earlier described. (KIERNAN, 1990). 


\subsection{Preparations of testicular tissues of rats of Groups I - V for biochemical analyses}

The testis of each rat was cut into small pieces, placed in a mortar and $0.1 \mathrm{M}$ phosphate buffer (extracting solution) of at least four times the volume of the organ was added. The organ was homogenized into fine solution with the use of mortar and pestle. The homogenate was poured into a test tube and centrifuged at 2,000 revolutions per minute for 10 minutes. The supernatant was carefully removed and the residue was discarded. The supernatant served as the sample for the estimations of Superoxide dismutase and Malondialdehyde Levels.

\subsection{Superoxide dismutase activity in testes bomogenates of Groups $I-V$}

Activities of Superoxide dismutase in testicular tissues of rats of Groups I - V were determined according to the protocol described in the assay kit of Randox Laboratories, United Kingdom.

\subsection{Lipid peroxidation status (Malondialdebyde Levels) in testes homogenates of Groups I - V}

The thiobarbituric acid assay (TBARS assay) method was used to quantify Malondialdehyde concentrations in testicular tissues of rats of Groups I - V as earlier described. (AKINLOLU, SALAU and AKINGBOLA, 2012).

\subsection{Sera collections for hormonal assays}

For testosterone and follicle stimulating hormone analyses, the rats of Groups I - V were dissected in the antero-median plane to expose the thoracic region immediately after euthanasia. Blood samples for hormonal assays were obtained from the heart through the ventricles with the aid of a $5 \mathrm{ml}$ syringe from all rats employed in the study. The serum was separated by centrifugation and the serum testosterone or follicle stimulating hormone levels were determined based on the principles described in assay kits of Randox Laboratories (United Kingdom).

\subsection{Evaluations of Follicle Stimulating Hormone (FSH) Levels in rats of Groups $I-V$}

The Microwell follicle stimulating hormone (FSH) EIA is a solid-phase enzyme immunoassay based on the 'sandwich' principle. Two separate antibodies directed against distinct antigenic determinants of the FSH molecule were utilized in the assay. The FSH present in the test sample reacted simultaneously with one antibody immobilized on the microwell surface and with another antibody conjugated to horseradish peroxidase enzyme forming an $\mathrm{Ab}-\mathrm{Ag}$ Ab-Enzyme complex on the microwell surface. Then the unbound conjugate was removed by washing and the colour development reagents (substrates) were added. Upon exposure, a colour change took place.

The intensity of the colour reflected the amount of bound anti-FSH enzyme conjugate and was proportional to the concentration of FSH in the specimen within the dynamic range of the assay. After stopping the reaction, the resulting colour was measured using a spectrophotometer at $450 \mathrm{~nm}$.

\subsection{Evaluations of testosterone levels in rats of Groups I - V}

The Micro well Testosterone EIA is a solid-phase enzyme immunoassay which utilizes the competitive binding principle. Testosterone present in the serum competed with enzyme-labeled testosterone for binding with antitestosterone antibody immobilized on the micro well surface. The amount of conjugate that bound to the micro well surface decreased in proportion to the concentration of testosterone in the serum. The unbound sample and conjugate were then removed by washing and the colour development reagents (substrates) were added. Upon exposure to the bound enzyme, a colour change took place.

The intensity of the colour reflected the amount of bound enzyme-testosterone conjugate and was inversely proportional to the concentration of testosterone in the serum within the dynamic range of the assay. After stopping the reaction the resulting colour was measured using a spectrophotometer at $450 \mathrm{~nm}$, and the testosterone concentration in the serum sample and concurrently run controls were determined from the standard curve.

\subsection{Statistical analyses}

The Mean \pm S.E.M (S.E.M. = Standard Error of Mean) value of each of the measured parameters of testicular functions (Follicle stimulating Hormone and Testosterone concentrations) and antioxidants status (Superoxide dismutase and Malondialdehyde Levels) in rats of Control Group I were compared with rats of Experimental Groups II - V for any significant difference using the Student's t-test for unpaired samples. P values of 0.05 (or less) were taken as statistically significant.

\section{Results}

\subsection{Changes in gross morphology, behavioural activities and average bodyweight (g) of rats of Groups I - V during experimental procedure}

No anomalies of gross morphology and behavioural activities were observed in rats of Control Group I and Experimental Groups II - V. Comparison of the average bodyweights of rats of Group I (Day l versus Day 35 ) showed statistically significant increased bodyweight $(\mathrm{P} \leq 0.05)$ at the end of five weeks of experimental procedures. (Table 1). In contrast, there was a statistically non-significant decreased average bodyweight $(\mathrm{P} \leq 0.05)$ in rats of Groups II - IV. (Day 1 versus Day 35). (Table 1 ). However, comparison of the average bodyweights of rats of Group V (Day l versus Day $35)$ showed statistically significant decreased bodyweight $(\mathrm{P} \leq 0.05)$ at the end of five weeks of experimental procedures. (Table 1). Furthermore, no anomaly of gross morphology of the testes was observed in rats of Groups I - V when they were dissected and removed for histological and biochemical analyses.

\subsection{Histological evaluations of the testes of rats of control and experimental Groups $I-V$}

Examinations of the testes of rats of Control Group 1 showed normal testicular histology. Histological examinations of the testes of rats of Experimental Groups II - V showed morphological anomalies such as disrupted 
and fewer collagen fibers of testicular connective tissues; poorly - defined interstitial spaces, disrupted seminiferous tubules, scanty spermatogenic cells and spermatozoa in a dose-dependent manner.

\subsection{Evaluations of superoxide dismutase activity}

Analyses of superoxide dismutase activities in testes homogenates showed statistically non-significant higher activities $(\mathrm{P} \leq 0.05)$ in rats of Experimental Groups II - V when compared to rats of Control Group I. (Figure 1).

\subsection{Evaluations of lipid peroxidation status (Malondialdehyde Concentrations)}

Analyses of Malondialdehyde concentrations in testes homogenates showed statistically significant higher concentrations $(\mathrm{P} \leq 0.05)$ in rats of Experimental Groups II - V when compared to rats of Control Group I. (Figure 2).

\subsection{Evaluations of Follicle Stimulating Hormone (FSH) levels}

Evaluations of serum Follicle Stimulating Hormone (FSH) levels showed statistically significant higher levels $(\mathrm{P} \leq 0.05)$ in rats of Experimental Groups II - V when compared to rats of Control Group I. (Figure 3).

\subsection{Evaluations of Testosterone levels}

Evaluations of serum Testosterone levels in rats of Experimental Groups II - V showed statistically significant higher levels $(\mathrm{P} \leq 0.05)$ when compared to rats of Control Group I. (Figure 4).

Table 1. Changes in Bodyweight ( $\mathrm{g}$ ) of Rats of Control and Experimental Groups I - V During Experimental Procedure. ( $\mathrm{P} \leq 0.05$ ).

\begin{tabular}{clcc}
\hline $\begin{array}{c}\text { Groups of } \\
\text { rats }\end{array}$ & \multicolumn{1}{c}{ Dose of Drugs } & Day l & Day 35 \\
\hline I & Distilled water & $152.50 \mathrm{~g}_{ \pm} 5.0$ & $180.00 \mathrm{~g}_{ \pm} 9.6$ \\
II & $5 \mathrm{mg} / \mathrm{kg} /$ bodyweight Azathioprine & $197.25 \mathrm{~g}_{ \pm} 1.1$ & $194.38 \mathrm{~g}_{ \pm} 1.3$ \\
III & $15 \mathrm{mg} / \mathrm{kg} /$ bodyweight Azathioprine & $212.50 \mathrm{~g}_{ \pm} 7.0$ & $191.88 \mathrm{~g}_{ \pm} 2.5$ \\
IV & $8 \mathrm{mg} / \mathrm{kg} /$ bodyweight Methotrexate & $207.50 \mathrm{~g}_{ \pm} 3.6$ & $196.57 \mathrm{~g}_{ \pm} 0.3$ \\
V & $20 \mathrm{mg} / \mathrm{kg} /$ bodyweight Methotrexate & $202.00 \mathrm{~g}_{ \pm} 9.0$ & $176.15 \mathrm{~g}_{ \pm} 3.1$ \\
\hline
\end{tabular}
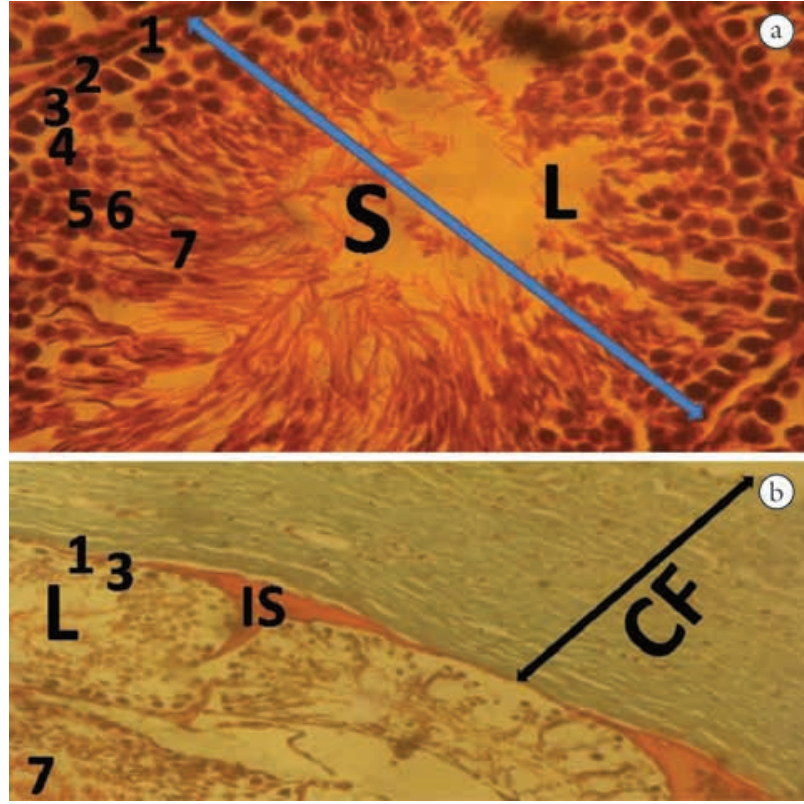

Figure 1. Photomicrographs of the testes of rats of Control Group I which received physiological saline. $1=$ Basement Membrane, 2 = Spermatogonium, 3 = Sertoli cell, $4=$ Primary spermatocyte, 5 = Secondary spermatocyte, 6 = Spermatid and 7 = Spermatozoa. $\mathrm{S}=$ Seminiferous Tubule (Blue Up and Down Arrow indicates the length of $S), L=$ Lumen of Seminiferous Tubule, IS = Interstitial Space (contains Leydig Cells), $\mathrm{CF}=$ Collagen Fibres of Tunica Albuginea and Vasculosa connective tissues (Black Up and Down Arrow indicates the length of $\mathrm{CF}$ ) and BV = Blood Vessel. The cytoarchitectural components of the testis appear normal. There are abundant collagen fibres in the testicular connective tissue and there is adequate quantity of sperm cells in the lumina of seminiferous tubules.
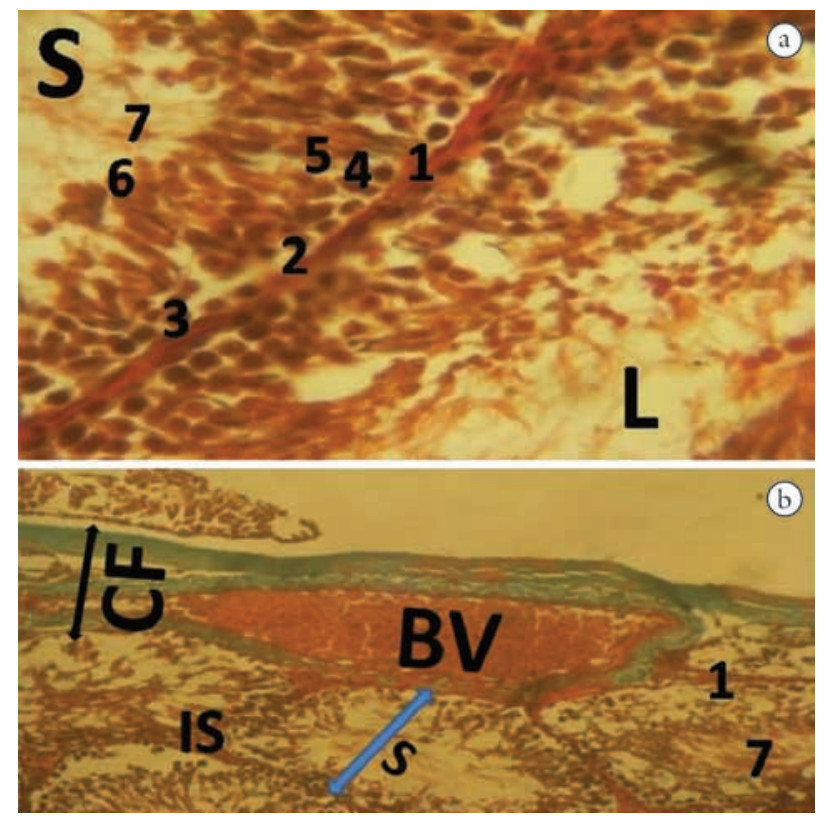

Figure 2. Photomicrographs of the testes of rats of Experimental Group II which received $5 \mathrm{mg} / \mathrm{kg} /$ bodyweight of Azathioprine. (a) Haematoxylin and Eosin X 100. (b) Masson's Trichrome X 400. 1 = Basement Membrane, 2 = Spermatogonium, 3 = Sertoli cell, 4 = Primary spermatocyte, $5=$ Secondary spermatocyte, $6=$ Spermatid and $7=$ Spermatozoa. $S=$ Seminiferous Tubule (Blue Up and Down Arrow indicates the length of S), $\mathrm{L}=$ Lumen of Seminiferous Tubule, IS = Interstitial Space (contains Leydig Cells), $\mathrm{CF}=$ Collagen Fibres of Tunica Albuginea and Vasculosa connective tissues (Black Up and Down Arrow indicates the length of $\mathrm{CF}$ ) and $\mathrm{BV}=$ Blood Vessel. (a) Observations of the lumen of some seminiferous tubules showed the presence of dead spermatozoa. (b) The cytoarchitectural components of the testis showed disrupted seminiferous tubules and fewer collagen fibers of testicular connective tissue. 

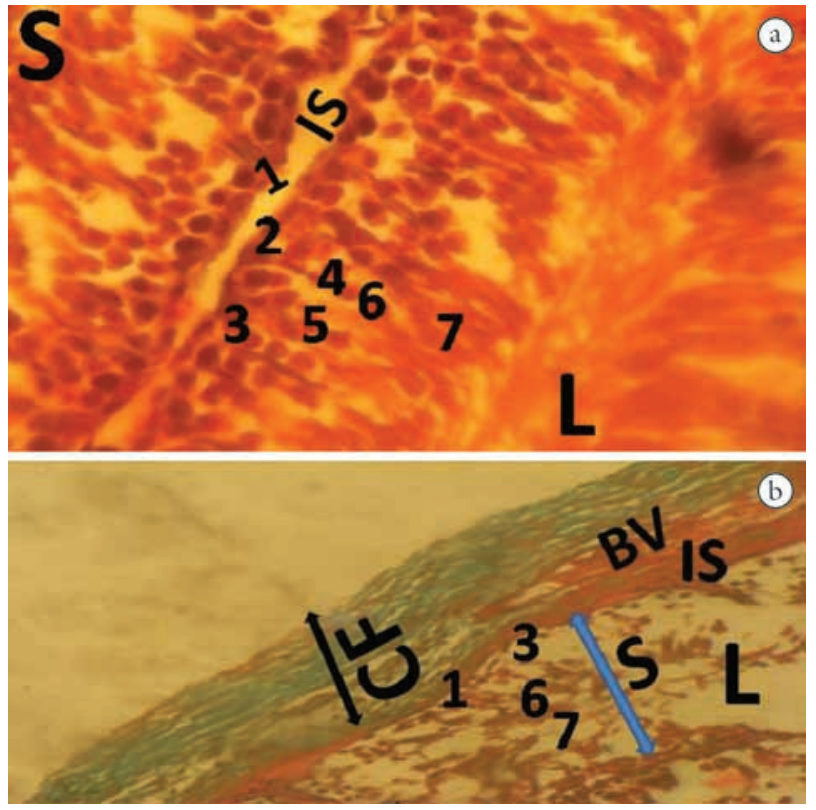

Figure 3. Photomicrographs of the testes of rats of Experimental Group III which received $15 \mathrm{mg} / \mathrm{kg} /$ bodyweight of Azathioprine. Haematoxylin and Eosin X 100. (b) Masson's Trichrome X 400. 1 = Basement Membrane, 2 = Spermatogonium, 3 = Sertoli cell, 4 = Primary spermatocyte, $5=$ Secondary spermatocyte, $6=$ Spermatid and $7=$ Spermatozoa. $S=$ Seminiferous Tubule (Blue Up and Down Arrow indicates the length of S), $\mathrm{L}=$ Lumen of Seminiferous Tubule, IS = Interstitial Space (contains Leydig Cells), $\mathrm{CF}=$ Collagen Fibres of Tunica Albuginea and Vasculosa connective tissues (Black Up and Down Arrow indicates the length of $\mathrm{CF}$ ) and $\mathrm{BV}=$ Blood Vessel. (a) Observations of the lumen of some seminiferous tubules showed the presence of numerous dead spermatozoa. (b) The cytoarchitectural components of the testis showed disrupted seminiferous tubules with scanty spermatogenic cells, dead spermatozoa and fewer collagen fibers of testicular connective tissue.

\section{Discussions}

No anomalies of gross morphology and behavioural activities were observed in rats of Groups I - V. Rats of Group I gained statistically significant average bodyweight throughout experimental procedure at $\mathrm{P} \leq 0.05$. (Table 1 ). However, statistically non-significant decreased average bodyweights (Groups II - IV) and significant decreased average bodyweights (Group V) were observed in rats of experimental groups in comparison of average bodyweights (Day 1 versus Day 35) at $\mathrm{P} \leq 0.05$. (Table 1 ). The observed weight loss in rats of Groups II - V could possibly be due to inhibition of DNA syntheses and increased oxidative stress with consequent cellular damage of body organs in affected rats. This agreed with the observations of (RUSSELL and RUSSELL, 1991), which reported weight loss in rats exposed to cytotoxic agents such as Azathioprine and Methotrexate.

Azathioprine and Methotrexate have been reported to result in structural and numerical anomalies of chromosomes including breaks in single DNA strands (NAGAFUCHI and MIYAZAKI, 1991); and induced oxidative damage to testicular tissues via lipid peroxidation. (BLASIAK, GLOC, WOZNIAK et al., 2002; PADMANABHAN, TRIPATHI,
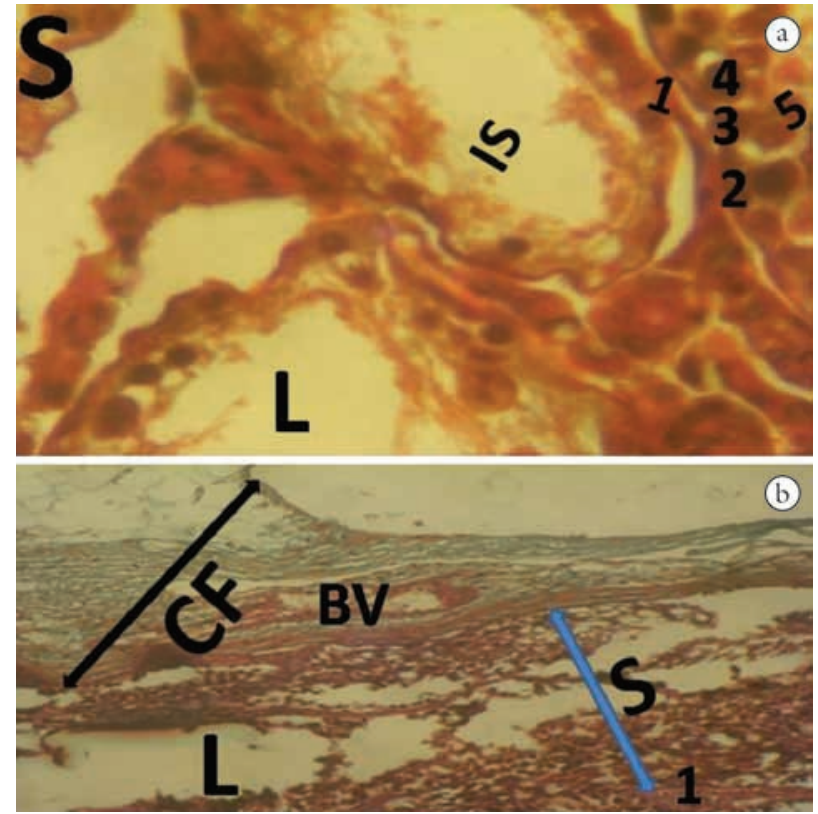

Figure 4. Photomicrographs of the testes of rats of Experimental Group IV which received $8 \mathrm{mg} / \mathrm{kg} /$ bodyweight of Methotrexate. (a) Haematoxylin and Eosin X 100. (b) Masson's Trichrome X 400. 1 = Basement Membrane, 2 = Spermatogonium, 3 = Sertoli cell, $4=$ Primary spermatocyte, $5=$ Secondary spermatocyte, $6=$ Spermatid and $7=$ Spermatozoa. $S=$ Seminiferous Tubule (Blue Up and Down Arrow indicates the length of S), $\mathrm{L}=$ Lumen of Seminiferous Tubule, IS = Interstitial Space (contains Leydig Cells), $\mathrm{CF}=$ Collagen Fibres of Tunica Albuginea and Vasculosa connective tissues (Black Up and Down Arrow indicates the length of $\mathrm{CF}$ ) and $\mathrm{BV}=$ Blood Vessel. Observations of the Lumen of some seminiferous tubules showed some dead spermatozoa. The cytoarchitecture of the testis showed disrupted seminiferous tubule while interstitial spaces, spermatogenic cells and spermatozoa could not be clearly distinguished. The collagen fibres component of testicular connective tissue appeared disrupted.

VIKRAM et al., 2009). Examinations of the testes of rats of Control Group 1 showed normal testicular histology. (Figure 1). However, histological examinations of the testes of rats of Experimental Groups II - V showed morphological anomalies such as disrupted and fewer collagen fibers of testicular connective tissues, poorly-defined interstitial spaces, disrupted seminiferous tubules, scanty spermatogenic cells and spermatozoa in a dose-dependent manner. (Figures 2-5). These observations possibly implied testicular anomalies via DNA or chromosomal damage following administrations of Azathioprine and Methotrexate.

Our observations are in agreement with previous studies which reported low sperm count in the caudal part of the epididymis (IWASAKI, IKEHARA, MURAKAMI et al., 2000); widening of interstitial spaces, dose-dependent disruption and atrophy of seminiferous tubules (PADMANABHAN, TRIPATHI, VIKRAM et al., 2009); cytoplasmic vacuolations and atrophied seminiferous tubules (KARAWYA and EL-NAHAS, 2006); and DNA damage, sperm abnormalities and poor antioxidant status in mice (ELELAIMY, ELFIKY, HASSAN et al., 2012) following Azathioprine administrations in animal models. Similarly, disrupted seminiferous tubules/epithelium (NOURI, 
AZARMI and MOVAHEDIN, 2009), widening of interstitial spaces and edema (NOURI, AZARMI and MOVAHEDIN, 2009); and decreased diameters of seminiferous tubules (SHRESTHA, DHUNGEL, SAXENA et al., 2007;
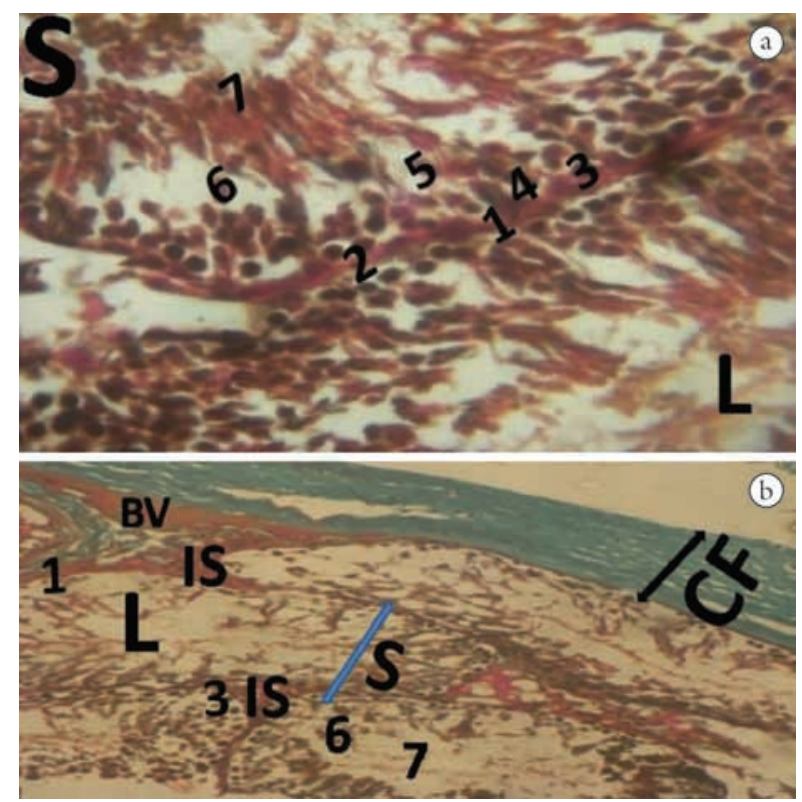

Figure 5. Photomicrographs of the testes of rats of Experimental Group Vwhich received $20 \mathrm{mg} / \mathrm{kg}$ / bodyweight of Methotrexate. (a) Haematoxylin and Eosin X 100. (b) Masson's Trichrome X 400. 1 = Basement Membrane, 2 = Spermatogonium, 3 = Sertoli cell, 4 = Primary spermatocyte, $5=$ Secondary spermatocyte, $6=$ Spermatid and $7=$ Spermatozoa. $S=$ Seminiferous Tubule (Blue Up and Down Arrow indicates the length of S), $\mathrm{L}=$ Lumen of Seminiferous Tubule, IS = Interstitial Space (contains Leydig Cells), $\mathrm{CF}=$ Collagen Fibres of Tunica Albuginea and Vasculosa connective tissues (Black Up and Down Arrow indicates the length of $\mathrm{CF}$ ) and $\mathrm{BV}=$ Blood Vessel. Some seminiferous tubules appeared disrupted while some lumen contain dead spermatozoa. The cytoarchitecture of the testis showed disrupted seminiferous tubules with scanty spermatozoa. The collagen fibres component of testicular connective tissue appeared disrupted.

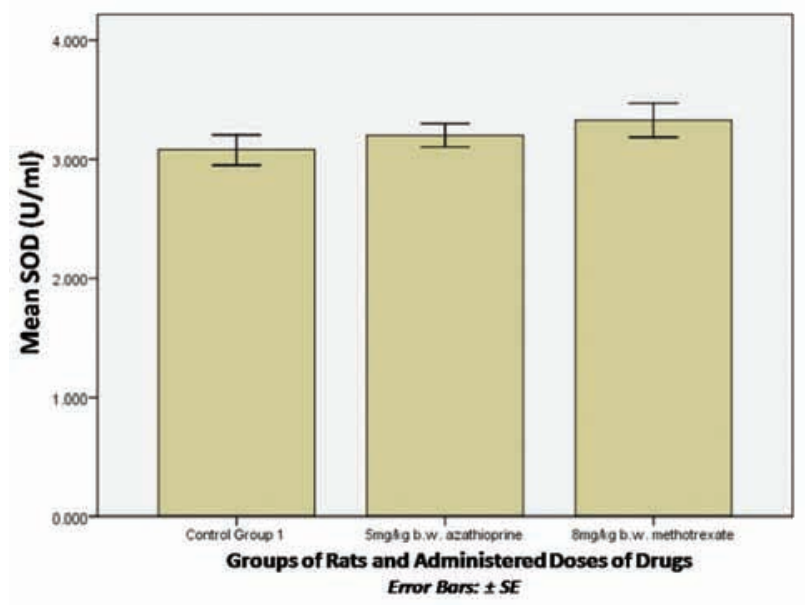

Figure 6. Graphical Analyses of Superoxide dismutase (SOD) Activity in Testes Homogenates of Rats of Control Group I and Experimental Groups II and III. SOD = Superoxide dismutase, $\mathrm{SE}=$ Standard Error and b.w. $=$ Bodyweight .
SERATI, KHAYAT, SAFAVI et al., 2009) were observed in Methotrexate-treated rats.

Statistical analyses of oxidation status showed nonsignificant higher activities $(\mathrm{P} \leq 0.05)$ of superoxide dismutase (Figure 6) and significant higher activities $(\mathrm{P} \leq 0.05)$ of malondialdehyde levels (Figure 7$)$ in testes homogenates of rats of Experimental Groups II - V when compared to rats of Control Group I. This implied increased oxidative stress in testicular tissues of rats of Groups II - V. Increased lipid peroxidation is associated with oxidative stress, compromised cell membranes and cellular damage in organisms. (AKINLOLU, OTULANA, OWOEYE et al., 2007). The observed morphological anomalies of the testes of rats of Groups II - V could, therefore, have been due to Azathioprine or Methotrexate - induced oxidative stress. This is in agreement with the observations of (BLASIAK, GLOC, WOZNIAK et al., 2002; PADMANABHAN, TRIPATHI, VIKRAM et al., 2009; ELELAIMY, ELFIKY, HASSAN et al., 2012), which reported induced oxidative damage to testicular tissues via lipid peroxidation in Azathioprine or Methotrexate - treated animals.

Statistical evaluations of serum Follicle Stimulating Hormone and Testosterone levels in rats of Experimental Groups II - V showed statistically significant higher levels $(\mathrm{P} \leq 0.05)$ when compared to rats of Control Group I. (Figures 8 and 9). Our finding suggests enzymatic defects and impaired status of the hypothalamo-pituitary-gonadal axis which regulates the syntheses and releases of gonadotropins (FSH and LH) and testosterone hormones (JUNQUEIRA and CARNEIRO, 2007; GUYTON and HALL, 2011). This is in agreement with observed impaired Leydig cells function in Azathioprine-treated rats (IWASAKI, IKEHARA, MURAKAMI et al., 2000); elevated FSH but reduced Testosterone levels and enzymatic defects of gonadal steroid synthesis in Methotrexate-treated rabbits (KOEHLER, HEINRICH, LUDWIG et al., 1986); and elevated FSH and Testosterone levels in Azathioprine or Methotrexate-treated rats (RUSSELL and RUSSELL, 1991).

This study, therefore, concluded that Azathioprine and Methotrexate impaired the morphology and functions of the testes in adult male wistar rats.

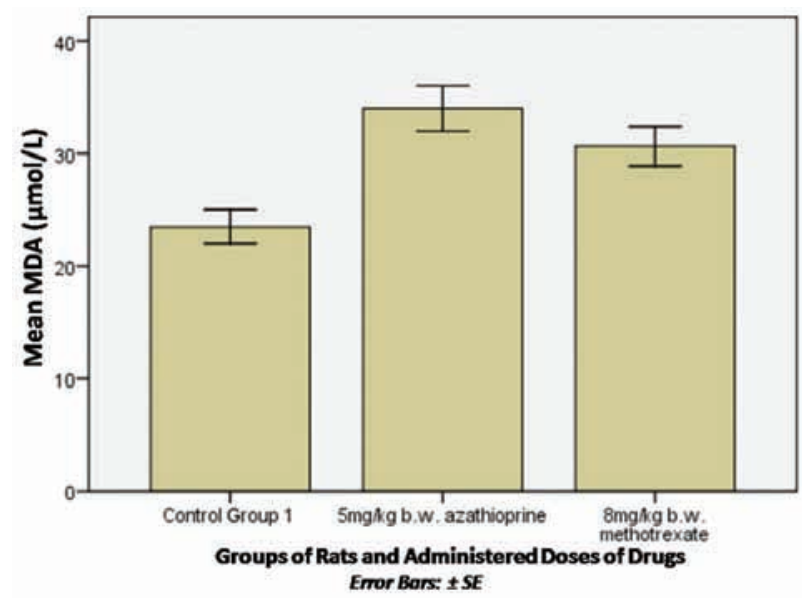

Figure 7. Graphical Analyses of Malondialdehyde (MDA) Concentrations in Testes Homogenates of Rats of Control Group I and Experimental Groups II and III. MDA = Malondialdehyde, $\mathrm{SE}=$ Standard Error and b.w. $=$ Bodyweight . 


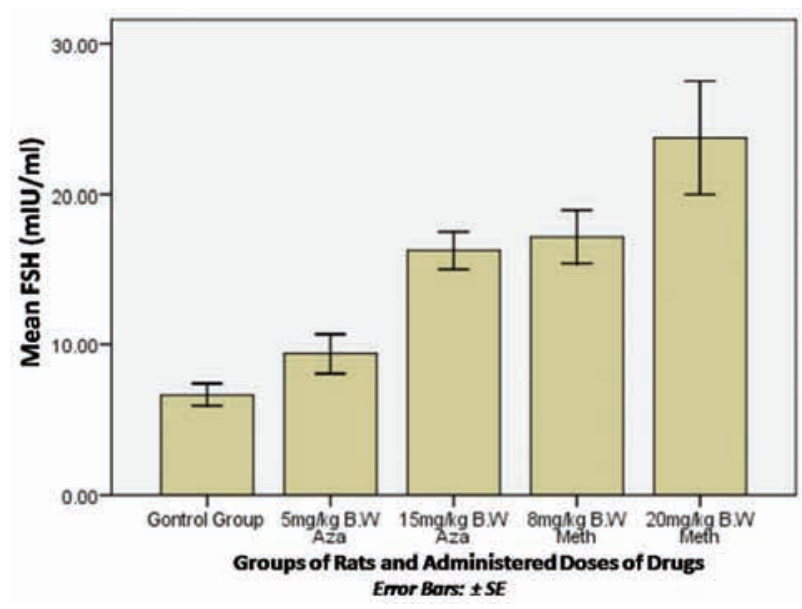

Figure 8. Graphical Analyses of Serum Follicle Stimulating Hormone (FSH) Concentrations in Rats of Control and Experimental Groups I - V. SE $=$ Standard Error, Aza=Azathioprine, Meth= Methotrexate, B.W= Bodyweight.

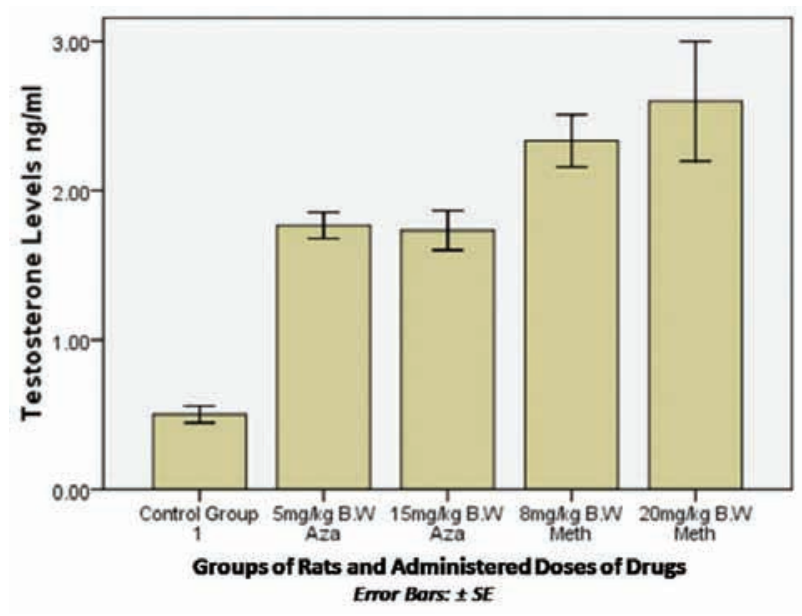

Figure 9. Graphical Analyses of Serum Testosterone Concentrations in Rats of Control and Experimental Groups I - V. $S E=$ Standard Error, Aza=Azathioprine, Meth= Methotrexate, B.W= Bodyweight.

\section{References}

AKINlOLU, AA., OTUlANA, JO., OWOEYE, O. and EJIWUNMI, AB. The antispermatogenic and antifertility effects of artemether on the testes of adult wistar rats. Pakistan Journal of Pathology, 2007, vol. 18, n. 2, p. 64-67.

AKINLOLU, AA., SALAU, BA. and AKINGBOLA, T. Lipid peroxidation in nigerians affected with heamatological malignancies. African Journal of Medicine and Medical Science, 2012, vol. 41, Supplement, p. 145-148. PMid:23678650.

BLASIAK, J., GLOC, E., WOZNIAK, K., MLYNARSKI, W., STOLARSKA, M., SKORSKI, T. and MAJSTEREK, I. Genotoxicity of idarubicin and its modulation by vitamins $\mathrm{C}$ and $\mathrm{E}$ and amifostine. Chemical Biological Interactions, 2002, vol. 140, n. 1, p. 1-18. http://dx.doi.org/10.1016/S0009-2797(02)00012-1

BRITISH MEDICAL ASSOCIATION and ROYAL PHARMACEUTICAL SOCIETY. British National Formulary. United Kingdom: Pharmaceutical Press, 2013. p. 583-585.
ELELAIMY, IA., ELFIKY, SA., HASSAN, AM., IBRAHIM, HM. and ELSAYAD, RI. Genotoxicity of anticancer drug Azathioprine

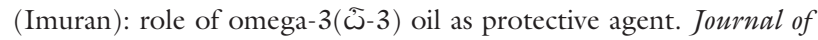
Applied Pharmaceutical Science, 2012, vol. 2, n. 4, p. 14.

GUYTON, A. and HALL, J. Guyton and Hall textbook of medical physiology. 12th ed. USA: Saunders, 2011. p. 979-984.

IWASAKI, M., IKEHARA, Y., MURAKAMI, K., MIZUNO, I., NAKAGAWA, O. and FUSE, H. Analysis of leydig cell dysfunction caused by Azathioprine in rats. Journal of Fertility and Sterility, 2000, vol. 45 , n. 1 , p. $43-47$.

JUNQUEIRA, LC. and CARNEIRO, J. Basic histology: text and atlas. 11th ed. New York: McGraw-Hill, 2007. Chapter 19.

KARAWYA, FD. and EL-NAHAS, AF. The protective effect of vitamin $\mathrm{C}$ on Azathioprine induced seminiferous tubular structural changes and cytogenetic toxicity in albino rats. Cancer Therapy, 2006, vol. 4, p. 125-134.

KIERNAN, JA. Histological and histochemical methods: theory and practice. 2nd ed. Oxford: Pergamon Press, 1990. p. 97-100.

KOEHLER, M., HEINRICH, U., LUDWIG, R., WALDHERR, R. and BRANDEIS, WE. Effects of methotrexate on rabbit testes. Part 2: Hormonal changes. Pediatric Hematology Oncology, 1986, vol. 3, n. 4, p. 335-341. PMid:3155255. http://dx.doi. org/10.3109/08880018609031235

NAGAFUCHI, K. and MIYAZAKI, K. Modulation of genotoxicity of Azathioprine by intracellular glutathione in hepatocytes. Journal of Cancer Research and Clinical Oncolology, 1991, vol. 117, n. 4, p. 321-325. PMid:2066352. http://dx.doi.org/10.1007/ BF01630714

NOURI, HS., AZARMI, Y. and MOVAHEDIN, M. Effect of growth hormone on testicular dysfunction induced by methotrexate in rats. Andrologia, 2009, vol. 41, n. 2, p. 105-110. PMid:19260847. http://dx.doi.org/10.1111/j.1439-0272.2008.00897.x

PADMANABHAN, S., TRIPATHI, DN., VIKRAM, A., RAMARAO, P. and JENA, GB. Methotrexate-induced cytotoxicity and genotoxicity in germ cells of mice: intervention of folic and folinic acid. Mutation Research, 2009, vol. 673, n. 1, p. 43-52. PMid:19110071. http://dx.doi.org/10.1016/j. mrgentox.2008.11.011

RUSSELL, LD. and RUSSELL, JA. Short-term morphological response of the rat testis to administration of five chemotherapeutic agents. American Journal of Anatomy, 1991, vol. 192, n. 2, p. 14268. PMid:1759681. http://dx.doi.org/10.1002/aja.1001920205

SERATI, NH., KHAYAT, NMH., SAFAVI, SE. and KHAKI, A. Histological and spermatogenesis indexes study of testis after Methotrexate administration in adult male rat. Journal of Birjand University of Medical Sciences, 2009, vol. 16, n. 3, p. 9-15.

SHRESTHA, S., DHUNGEL, S., SAXENA, AK., BHATTACHARYA, S. and MASKEY, D. Effect of methotrexate (MTX) administration on spermatogenesis: an experimental on animal model. Nepal Medical College Journal, 2007, vol. 9, n. 4, p. 230-233. PMid:18298010.

TRIPATHI, KD. Essentials of medical pharmacology. 5th ed. India : Jaypee Brothers Medical Publishers, 2003. p. 769-774.

Received July 15, 2013 Accepted May 15, 2014 